\title{
Distribution of Juxtaglomerular Cells in the Kidney of the Red Batfish*1
}

\author{
Mikio Oguri*2 \\ (Received July 9, 1992)
}

\begin{abstract}
Histologic examination was made on the distribution pattern of juxtaglomerular (JG) cells in the aglomerular kidney of the red batfish Halieutaea stellata. In this examination, five specimens ( 71 to $183 \mathrm{~g}$ in body weight) were used and serial histologic sections were prepared from left and right kidneys ( 0.26 to $0.89 \mathrm{~g}$ in combined weight) of these specimens. From detailed histologic observation performed on the whole sections, it was ascertained that JG cells were localized as clusters in several regions within the kidney and the number of cell clusters was 3 to 10 and 4 to 10 in the left and right kidney tissues, respectively.
\end{abstract}

In mammalian kidneys, juxtaglomerular (JG) cells are located in the wall of the afferent arteriole near the renal glomerulus. By recent immunohistochemical studies $^{1-5}$ on mammalian kidneys, the cells have been ascertained to contain renin, a renal peptide hormone, belonging to the so-called renin-angiotensin system. The JG cells are also present in the teleostean kiddeys, and are detectable even in aglomerular fish. ${ }^{8-14)}$ For the aglomerular kidney the terminology of JG cells is not appropriate, but I have adopted this term in previous publications, ${ }^{B-12,14)}$ because JG cell is a well-known term for renin-containing cells in vertebrate kidneys. So I shall also use this term in the present report.

Using several species of aglomerular teleost, I have hitherto carried out histological investigations on the JG cell distribution in aglomerular kidneys and found various distribution patterns of the cell. ${ }^{\theta-12,14)}$ As a continuation report, the present paper deals with JG cell distribution in the kidney of the red batfish Halieutaea stellata, which was reported to be an aglomerular fish in my recent publication. ${ }^{13)}$

\section{Materials and Methods}

In this study I used five specimens of the red batfish $H$. stellata (Ogcocephalidae). They ranged in body weight from 71 to $183 \mathrm{~g}$. These fish were collected in Suruga Bay, Shizuoka Prefecture, and were supplied to me through the courtesy of Messrs. G. Nishi and K. Kobayashi, Marine Science Museum, Tokai University, Shimizu City.

The whole kidneys were removed from these fishes. The organs ranged in weight from 0.26 to $0.89 \mathrm{~g}$ and were fixed in Bouin's or Helly's fluid. The fixed materials were dehydrated in ethanol series and embedded in paraffin. Then total serial sections were made at a thickness of $6-7 \mu \mathrm{m}$. As for staining, Mayer's acid hemalum and eosin were used for the sections fixed in Bouin's fluid and Bowie's stain ${ }^{1 t^{()}}$was employed for those fixed in Helly's fluid.

\section{Results and Discussion}

As illustrated in Fig. 1A, the kidney of the red batfish is composed of two separate renal masses bean-like in shape, and the portion known as the head kidney is not discernible in this fish. Using ten renal masses from five batfishes, detailed light-microscopic examinations were performed on the total histologic sections made from whole kidneys. During observation of the sections stained with H-E, abundant epithelioid cells were detected around the sinusoidal blood vessels in the interstitial tissue of the kidney (Fig. 2A). They are moderately eosinophilic, as shown in Fig. 2A. With Bowie's stain the cytoplasm of these cells took on an intense bluish-purple color as seen in Figs. 2B and 2C. Therefore, these epithelioid cells are Bowie-positive and are regard-

*1 The outline of this report was presented at the Meeting of the Japanese Society of Scientific Fisheries, April, 1992.

*2 Laboratory of Fish Biology, Faculty of Agriculture, Nagoya University, Nagoya 464-01, Japan (小栗幹 郎: 名古屋大学素学部). 

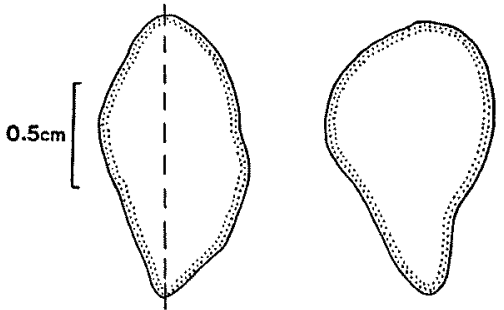

Fig. 1A. Ventral view of the right and left kidneys of the red batfish (specimen No. 4). Top and bottom indicate anterior and posterior parts of the kidney, respectively.

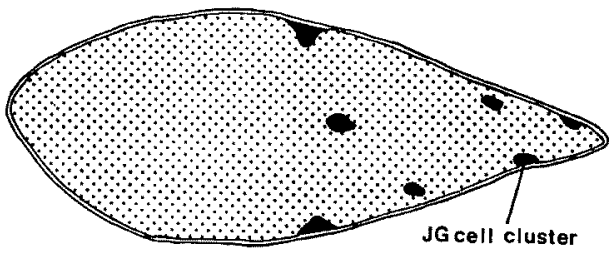

Fig. 1B. Diagrammatic figure showing the distribution of JG cell clusters on the longitudinal section (broken line in Fig. 1A) of the right kidney. Left and right indicate anterior and posterior parts of the kidney, respectively.

ed as the JG cells described previously in my publications on various aglomerular kidneys. ${ }^{a-12,14)}$ Recently, renin was demonstrated in teleostean JG cells by an immunohistochemical method. ${ }^{13,17,18)}$ Furthermore, the renin-immunoreactive cells have been ascertained to be Bowie-positive cells. ${ }^{17,18)}$

The JG cell cluster shown in Figs. $2 \mathrm{~B}$ and $2 \mathrm{C}$ was detectable in several regions of renal parenchyma. So, using five specimens of the batfish, the number of clusters was counted throughout the whole kidney area. The results are summarized in Table 1. In the right and left kidneys of five specimens, the number of JG cell clusters was $4-10$ and 3-10, respectively. As an example, Fig. 1B is a graphic representation of the intrarenal distribution of seven JG cell clusters in the right kidney of fish No. 4. As shown in this figare, these cell clusters were detected in the middle and posterior regions of the kidney. Thus, it is clearly demonstrated that JG cell clusters in the red batfish were distributed in several areas of renal parenchyma.

I have hitherto reported four types of distribution pattern of JG cells in aglomerular kidneys. The first type is seen in the kidney of the toadfish Opsanus tau, where JG cells were diffusely distributed in the whole area of the kidney, localizing mainly in the wall of small and medium-sized blood vessels situated in the interstitial tissue of the kidney. ${ }^{9-12}$ ) The second type is found in the anglerfish Lophius litulon. In this type, JG cells are distributed as clusters in several regions of the kidney..$^{9-11}$ Usually, these cells are located in the superficial region of the kidney. Furthermore, JG cells were detectable occasionally in the deeper region within the kidney. In the third type, JG cells are observed only in one limited peripheral subcapsular region of the kidney. This type was reported in the sargassum fish Histrio histrio and the frogfishes Phrynelox nox and $P$. tridens. ${ }^{9-11}$ ) Finally, in the fourth type, the cluster of JG cells is present in the extrarenal connective tissue between the parenchymal portion of the kidney. This type is seen in the shortnosed sea horse Hippocampus brevirostris. ${ }^{\text {14) }}$

As described above, the distribution pattern of JG cells in the anglerfish resembles the pattern in the red batfish of the present study. However, the anglerfish used in the study on JG cell distribution were four large specimens, ranging in body weight from 2.5 to $8.6 \mathrm{~kg}$. Thus their kidneys were also large in size, and the weights of right and left kidneys were $3.7-14.9$ and $3.2-13.4 \mathrm{~g}$,

Table 1. Distribution of juxtaglomerular cell clusters in the kidney of the red batfish

\begin{tabular}{cccccc}
\hline No. & Sex & Body weight & Kidney weight $*$ & \multicolumn{2}{c}{ Number of juxtaglomerular cell clusters } \\
\cline { 5 - 6 } & & & & Right kidney & Left kidney \\
\hline 1 & F & $71 \mathrm{~g}$ & $0.26 \mathrm{~g}$ & 4 & 3 \\
2 & M & 98 & 0.40 & 10 & 6 \\
3 & M & 106 & 0.30 & 10 & 4 \\
4 & F & 115 & 0.57 & 7 & 10 \\
5 & M & 183 & 0.89 & 7 & 10 \\
\hline
\end{tabular}

F, female; M, male. * Combined weight of right and left kidneys. 

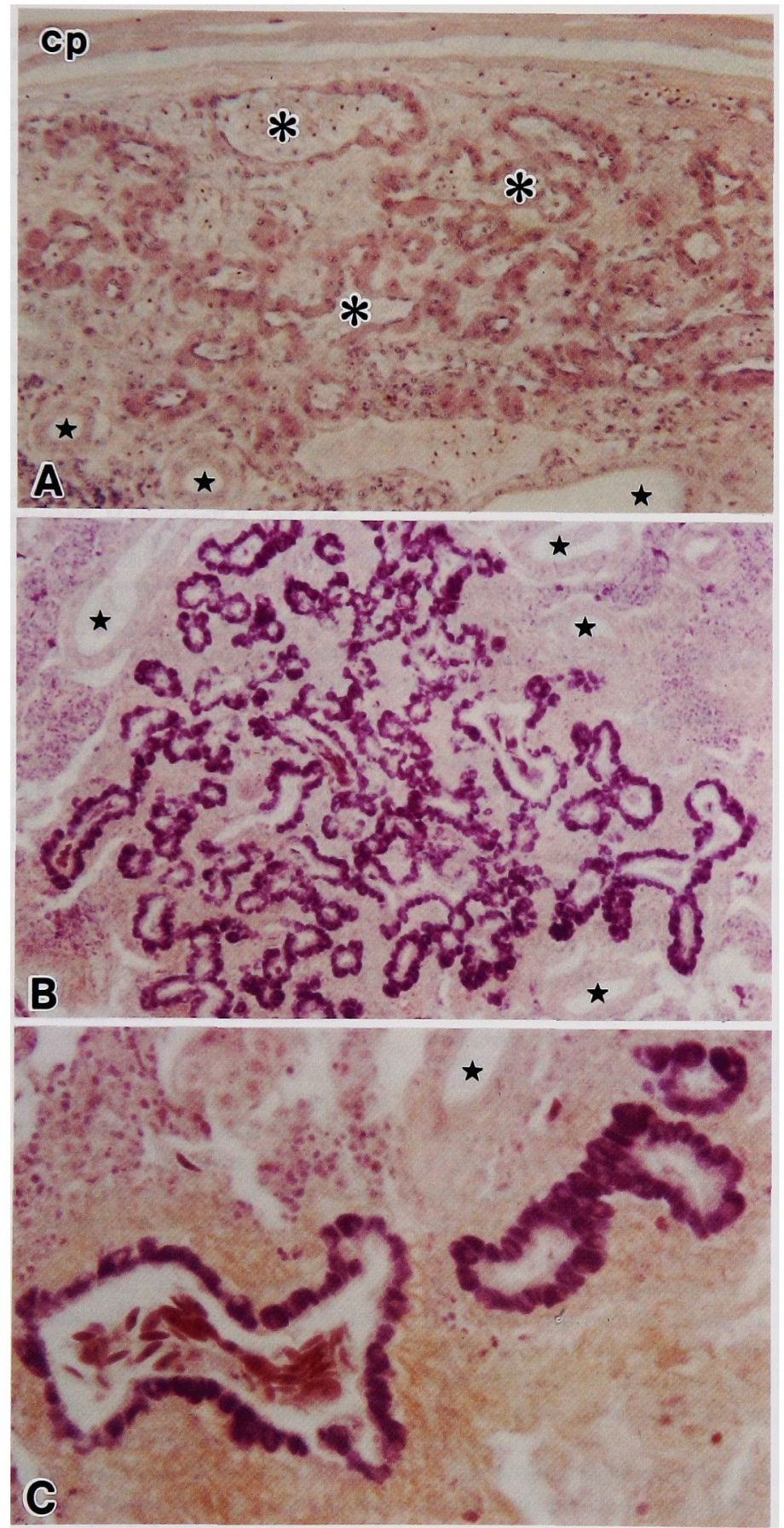

Fig. 2. Juxtaglomerular (JG) cells in the kidneys of the red batfish.

Asterisk indicates the renal tubule.

Fig. A: H-E stain, $\times 260$. cp, capsule of the kidney; $*$ indicates some of the sinusoidal blood vessels surrounded by JG cells.

Figs. B and C: JG cells are shown in bluish-purple color with Bowie's stain. (sinusoidal blood vessels) Fig. B. $\times 205$, Fig. C. $\times 475$. 
respectively.* Accordingly, it is not easy to obtain exact information about JG cell distribution from such large kidneys. In contrast, the red batfish is small and the total weights of right and left kidneys of the specimens used in the present study were $0.26-0.89 \mathrm{~g}$ as shown in Table 1. Such a small size of kidney tissue was suitable for detailed histologic examination on JG cell distribution within the whole kidney. Consequently, the first detailed information on the second type of JG cell distribution was obtained from the present study using the kidney of the red batfish.

\section{Acknowledgements}

I wish to thank Messrs. G. Nishi and K. Kobayashi, Marine Science Museum, Tokai University, for supplying valuable fish materials. I am also indebted to Mrs. K. Koga for her excellent technical assistance.

\section{References}

1) T. Tanaka, E. W. Gresik, A. M. Michelakis, and T. Barka: Immunocytochemical localization of renin in kidneys and submandibular glands of SWR/J and C57BL/6J mice. $J$. Histochem. Cytochem., 28, 1113-1118 (1980).

2) R. Taugner and E. Hackenthal: Angiotensin II in epitheloid (renin containing) cells of rat kidney. Histochemistry, 72, 499-509 (1981).

3) T. Faraggiana, E. Gresik, T. Tanaka, T. Inagami, and A Lupo: Inmunohistochemical localization of renin in the human kidney. I. Histochem. Cytochem, 30, 459-465 (1982).

4) R. Taugner, E. Mannek, R. Nobiling, C. P. Bührle, E. Hackenthal, D. Ganten, T. Inagami, and H. Schröder: Coexistence of renin and angiotensin II in epithelioid cell secretory granules of rat kidney. Histochemistry, 81, 39-45 (1984)
5) R. Taugner and E. Hackenthalt The Juxtaglomerular Apparabis, Springer-Vetlag Berin \& Heidelberg, 1989, pp. 6989.

6) A. Bohle and W. Walvig Beitrag zur vergleichender Mo phologie der epitheloiden Zzellen der Nierenarteriolen unter besonderer Berticksichtigung der epitheloiden Zellen in den Nieren von Seewassertischen. Klin. Wochenschr., 42, 415421 (1964),

7) S. V. Capréol and L. E. Sutherland: Comparative morphology of juxtaglometular cells. I. Juxtaglomerular cells in fish. Can, J. Zool., 46, 249-256 (1968).

8) M. Oguri and $H$. Sokabe. Juxtaglomerular cells in the teleost kidneys. Nippon Suisan Gakkaish4, 34, 882-888 (1968).

9) M. Oguri, M. Ogawa, and H. Sokabe: Jataglomerular cells in aglotnerular teleasts. Nippon Suisan Gakkaishi, 38, 195-200 (1972).

10) M. Ogawa, M. Oguri, H. Sokabe, and H. Nishimura: Juxtaglomerular apparatus in the vertebrates. Gen. Comp. Endocrinal., Suppl., 3, 374-381 (1972),

11) M. Oguri: in "Hormones, Adaptation and Evolution" (ed. by $\mathbf{S}$. Ishii, T. Hirano, and M. Wada), Japan Sci. Soc. Press, Tokyo and Springer-Verlag, Berlin, 1980, p. 318.

12) M. Oguri: On the distribution of the juxtaglomerular cells in toadfish kidney. Nippon Suisan Gakkaishi, 47, 453-455 (1981).

13) J. A. Christensen, R. Taugner, D. S. Meyer, and A. Bohle: The granular epithelioid cells in the kidney of the lemon sole (Pleuronectes microcephalus Donovani). Cell Tiss. Res., 249, 137-143 (1987).

14) M. Oguri: Distribution of renal juxtaglomerular cells in the shortnosed sea horse Hippocampus brevirostris. Nippon Suisan Gakkaishi, 55, 1379-1381 (1989).

15) M. Oguri: Kidney of the red batfish Halieutaea stellota as aglomerular type. Nippon Suisan Gakkaishi, 55, 743 (1989).

16) D. J. Bowie: A method for staining the pepsinogen granules in gastric glands. Anat. Rec., 64, 357-367 (1936).

17) Y. Kon, Y. Hashimoto, H. Kitazawa, and N. Kudo: Morphological and immunohistochemical studies of juxtaglomerular cells in the carp, Cyprinus carpio. Jpn. J. Vet, ScF, 49, 323-331 (1987).

18) H. Tazawa, M. Mukal, and M. Ogawa: Immunohistochemical studies of juxtaglomerular cells and the corpuscles of Stannius in the eel, Anguilla japonica. Zool. Sci., 6, 805-808 (1989).

\footnotetext{
* M. Oguri: unpublished data.
} 